\title{
Karakteristik Dengue Berat yang Dirawat di Pediatric Intensive Care Unit
}

\author{
Dzulfikar D. Lukmanul Hakim, Wiwin Winiar, Herry Garna \\ Departemen Ilmu Kesehatan Anak Fakultas Kedokteran Universitas Padjajaran \\ Rumah Sakit Dr. Hasan Sadikin Bandung
}

\begin{abstract}
Abstrak
Virus dengue dapat menyebabkan infeksi pada semua kelompok usia dengan manifestasi klinis beragam mulai dari asimtomatik, ringan, sampai berat yang biasanya merupakan kasus fatal. Dengue berat ditandai dengan kebocoran plasma, hemokonsentrasi, dan gangguan hemostasis. Penelitian ini bertujuan untuk mengetahui karakteristik penderita dengue berat yang dirawat di ruang Pediatric Intensive Care Unit (PICU) RS Dr. Hasan Sadikin Bandung sejak Januari 2009 sampai Desember 2010. Penelitian dilakukan secara retrospektif deskriptif berdasarkan data dari rekam medis penderita. Sebanyak 21 penderita dengue berat dirawat selama 2 tahun, 15/21 penderita perempuan dan 6/21 laki-laki, serta 5/21 anak meninggal dunia selama dirawat dengan sebab kematian tersering sindrom syok dengue (SSD) dan kogagulopati intravaskular diseminata (KID). Sebagian besar penderita berusia 1-5 tahun dengan status gizi baik. Hepatomegali ditemukan pada semua penderita dengan hematokrit rata-rata 38\%. Pada penelitian ini, manifestasi klinis dengue berat berupa SSD (15/21), KID (11/21), ensefalopati (6/21), efusi pleura (5/21), miokarditis (3/21), serta acute respiratory distress syndrome (3/21). Simpulan, dengue berat lebih banyak didapatkan pada anak perempuan, usia 1-5 tahun, serta status gizi baik. Manifestasi klinis dengue berat yang dominan berupa syok, koagulasi intravaskular diseminata, dan ensefalopati. [MKB. 2012;44(3):147-51].
\end{abstract}

Kata kunci: Dengue berat, karakteristik, pediatric intensive care unit

\section{Characteristic of Severe Dengue Hospitalized in Pediatric Intensive Care Unit}

\begin{abstract}
Dengue viral infections affect all age groups and produce a spectrum of clinical illness that ranges from asymptomatic to severe and occasionally fatal disease. Severe dengue characterized by plasma leakage, hemoconcentration, and hemostatic disorder. The aim of this study was to know the characteristic of severe dengue patients admitted to Pediatric Intensive Care Unit (PICU) Dr. Hasan Sadikin Hospital Bandung during January 2009 to December 2010. This was a retrospective descriptive study based on the data collected from the medical records. Twenty-one severe dengue cases in two years were admitted 15/21 girls and 6/21 boys, and 5/21 of them died during hospitalization because of dengue shock syndrome (DSS) and disseminated intravascular coagulation (DIC). Most of them were 1-5 years old with good nutritional status. Hepatomegaly was found in all cases with mean hematocrit was $38 \%$. In this research, the most manifestation of severe dengue were DSS (15/21), DIC (11/21), encephalopathy $(6 / 21)$, pleural effusion $(5 / 21)$, myocarditis $(3 / 21)$, and acute respiratory distress syndrome $(3 / 21)$. In conclusions, severe dengue are more common in girls, 1-5 years old, and well-nourished children. The most common clinical manifestation of severe dengue are shock, disseminated intravascular coagulation, and encephalopathy.
\end{abstract} [MKB. 2012;44(3):147-51].

Key words: Characteristic, pediatric intensive care unit, severe dengue

Korespondensi: Dzulfikar D. Lukmanul Hakim, dr., Sp.A(K), M.Kes, Departemen Ilmu Kesehatan Anak Fakultas Kedokteran Universitas Padjadjaran-Rumah Sakit Dr. Hasan Sadikin, jalan Pasteur No. 38 Bandung 40161, Indonesia, telepon (022) 2035957, mobile 081394799550 


\section{Pendahuluan}

Infeksi virus dengue merupakan mosquitoborne viral disease paling penting yang mengenai manusia di seluruh dunia. Penyakit ini merupakan masalah kesehatan utama di daerah tropis dan subtropis. Keempat serotipe virus dengue yang merupakan virus RNA single stranded, famili Flaviviridae, menyebabkan spektrum klinis yang luas, mulai dari infeksi dengue yang asimtomatik sampai berat. Sebelumnya infeksi virus dengue dibagi menjadi 3 kategori menurut World Health Organization (WHO) 1997, yaitu demam dengue (DD), demam berdarah dengue (DBD), dan undifferentiated fever. Menurut WHO tahun 2009, infeksi dengue dibagi menjadi 2 kelompok utama, yaitu dengue (dengan atau tanpa tanda peringatan) serta dengue berat. Faktor risiko terjadinya dengue berat adalah infeksi sekunder dengan serotipe virus berbeda. Beratnya penyakit selama infeksi dengue sekunder berhubungan dengan puncak titer virus dalam plasma yang lebih tinggi. ${ }^{1,2}$ Beberapa penelitian menunjukkan bahwa faktor pejamu dan virulensi strain virus juga dapat dipertimbangkan sebagai faktor risiko potensial. ${ }^{1-5}$

Insidensi infeksi virus dengue pada saat ini meningkat 30 kali lipat sejak 50 tahun yang lalu dengan ekspansi geografis ke negara baru. World Health Organization (WHO) memperkirakan sekitar 50 juta orang terinfeksi virus dengue setiap tahunnya dan sekitar 2,5 miliar penduduk tinggal di negara endemis. Di Indonesia lebih dari $35 \%$ populasinya tinggal di daerah perkotaan, dilaporkan terdapat 150.000 kasus dan lebih dari 25.000 kasus berasal dari Jakarta dan Jawa Barat. ${ }^{1}$ Angka mortalitas akibat virus dengue diperkirakan sekitar 5\% atau 25.000 kematian tiap tahun dan terutama terjadi pada anak berusia di bawah 15 tahun. Mortalitas karena sindrom syok dengue (SSD) dapat mencapai 44\%. ${ }^{1,6}$ Jumlah kasus infeksi dengue yang dirawat di Departemen Ilmu Kesehatan Anak RS Dr. Hasan Sadikin Bandung sebanyak 1.048 kasus pada tahun 2009 dan kemudian mengalami penurunan menjadi 595 kasus pada tahun 2010. Jumlah penderita yang meninggal sebanyak 5 orang pada tahun 2009, sedangkan pada tahun 2010 sebanyak 3 orang. Jumlah penderita dengue berat yang dirawat di Pediatric Intensive Care Unit berturut-turut sebanyak 14 dan 7 kasus pada tahun 2009 dan 2010. Jumlah penderita yang meninggal di Pediatric Intensive Care Unit (PICU) RS Dr. Hasan Sadikin Bandung karena dengue berat sebanyak 2 dan 3 kasus pada tahun 2009 dan 2010.Penelitian ini bertujuan untuk mengetahui karakteristik penderita dengue berat yang dirawat di PICU RS Dr. Hasan Sadikin Bandung.

\section{Metode}

Penelitian merupakan retrospektif deskriptif berdasarkan data rekam medis penderita DBD dengan komplikasi.

Subjek penelitian semua anak dengue berat yang dirawat di PICU Rumah Sakit Dr. Hasan Sadikin Bandung selama periode 2009-2010.

Diagnosis dengue berat ditegakkan berdasarkan kriteria WHO tahun 2009 terdiri atas: (1) kebocoran plasma yang hebat dengan peningkatan hematokrit yang menyebabkan syok, akumulasi cairan (pleura, asites), distres napas; (2) perdarahan hebat; (3) gangguan organ yang berat: hati ditandai dengan peningkatan transaminase (SGOT/SGPT $\geq 1.000 \mathrm{U} / \mathrm{L}$ ) dan gangguan susunan saraf pusat berupa gangguan kesadaran dan kejang. ${ }^{1}$

Data yang dikumpulkan meliputi jenis kelamin, usia, status gizi, hematokrit, trombosit, hasil pemeriksaan serologis, lama perawatan di PICU, komplikasi yang terjadi, serta apakah penderita hidup atau meninggal dunia.

Status gizi dinilai berdasarkan WHO Child Growth Standard 2007. Jika berat badan menurut panjang badan atau indeks massa tubuh menurut usia di bawah -2 standar deviasi dimasukkan ke dalam malnutrisi, gizi baik berada pada rentang -1 sampai dengan $1 \mathrm{SD}$, gizi lebih (overweight) jika di atas $1 \mathrm{SD}$, dan obes bila di atas $2 \mathrm{SD}^{7}$

Infeksi primer ditandai dengan tidak ditemukannya antibodi IgG spesifik dengue pada serum akut, sedangkan infeksi sekunder ditunjukkan dengan ditemukannya IgG pada fase akut, dengan atau tanpa ditemukannya IgM.,

\section{Hasil}

Selama periode penelitian terdapat 21 penderita dengue berat yang dirawat di PICU RS Dr. Hasan Sadikin Bandung, 14 kasus tahun 2009 dan 7 kasus tahun 2010.

Sebagian besar penderita $(15 / 21)$ berjenis kelamin perempuan dengan status gizi baik. Hepatomegali ditemukan pada semua kasus. Manifestasi klinis dengue berat paling banyak berupa SSD sebanyak 15/21 penderita, diikuti koagulasi intravaskular diseminata (KID) pada $11 / 21$ penderita, dan ensefalopati $6 / 21$ penderita (Tabel 1).

Hematokrit rata-rata sebesar 38\% dengan kadar trombosit berkisar antara 9.000 sampai 208.000/ $\mathrm{mm}^{3}$ dan rata-rata $65.500 / \mathrm{mm}^{3}$. Pemeriksaan serologis didapatkan sebanyak 14/21 mengalami infeksi sekunder ditandai dengan IgM dan IgG positif (Tabel 2). 
Tabel 1 Karakteristik dan Komplikasi Dengue Berat

\begin{tabular}{|c|c|}
\hline Karakteristik & Jumlah \\
\hline $\begin{array}{l}\text { Jenis kelamin } \\
\text { Perempuan } \\
\text { Laki-laki }\end{array}$ & $\begin{array}{r}15 \\
6\end{array}$ \\
\hline $\begin{array}{l}\text { Usia (tahun) } \\
1-5 \\
5-10 \\
>10\end{array}$ & $\begin{array}{r}12 \\
8 \\
1\end{array}$ \\
\hline $\begin{array}{l}\text { Status gizi } \\
\text { Obes } \\
\text { Gizi lebih } \\
\text { Gizi baik } \\
\text { Malnutrisi ringan }\end{array}$ & $\begin{array}{r}0 \\
2 \\
16 \\
3\end{array}$ \\
\hline Hepatomegali & 21 \\
\hline $\begin{array}{l}\text { Komplikasi } \\
\text { SSD } \\
\text { KID } \\
\text { Ensefalopati } \\
\text { Disfungsi organ multipel } \\
\text { ARDS } \\
\text { Miokarditis } \\
\text { Efusi pleura bilateral } \\
\text { Edema paru } \\
\text { Perdarahan intrakranial }\end{array}$ & $\begin{array}{r}15 \\
11 \\
6 \\
0 \\
3 \\
3 \\
5 \\
2 \\
1\end{array}$ \\
\hline $\begin{array}{l}\text { Lama perawatan } \\
<24 \text { jam } \\
1-5 \text { hari } \\
>5 \text { hari }\end{array}$ & $\begin{array}{l}3 \\
9 \\
9\end{array}$ \\
\hline Hidup & 16 \\
\hline Meninggal & 5 \\
\hline
\end{tabular}

Keterangan: SSD: sindrom syok dengue, KID: koagulasi intravaskular diseminata, ARDS: acute respiratory distress syndrome

\section{Pembahasan}

Infeksi virus dengue menyerang semua kelompok usia dengan spektrum klinis beragam mulai dari asimtomatik sampai dengan berat yang biasanya ditandai dengan syok dan perdarahan. ${ }^{2}$ Infeksi dengue dapat diduga pada penderita yang mengeluh demam yang tinggal/riwayat bepergian ke daerah endemik dengue disertai gejala mual, muntah, ruam, sakit kepala, nyeri sendi, uji tourniquet positif, terdapat tanda bahaya, serta serologis dengue positif (pemeriksaan ini penting jika tidak ditemukan tanda kebocoran plasma). ${ }^{1,2}$ Tanda bahaya meliputi nyeri perut, muntah terus-menerus, akumulasi cairan, perdarahan mukosa, letargis, gelisah, hepatomegali $>2 \mathrm{~cm}$, dan pada pemeriksaan laboratorium didapatkan peningkatan hematokrit disertai penurunan jumlah trombosit yang cepat. ${ }^{1,2}$
Tabel 2 Pemeriksaan Laboratorium pada Dengue Berat

\begin{tabular}{lc}
\hline \multicolumn{1}{c}{ Laboratorium } & Hasil \\
\hline Nilai hematokrit & \\
$\geq 35 \%$ & 9 \\
$<35 \%$ & 12 \\
Nilai hematokrit rata-rata & $38 \%$ \\
Jumlah trombosit terendah & $9.000 / \mathrm{mm}^{3}$ \\
Jumlah trombosit tertinggi & $208.000 / \mathrm{mm}^{3}$ \\
Jumlah trombosit rata-rata & $65.500 / \mathrm{mm}^{3}$ \\
Serologis & \\
IgG $(+), \operatorname{IgM}(-)$ & 2 \\
$\operatorname{IgG}(-), \operatorname{IgM}(+)$ & 5 \\
$\operatorname{IgM}(+), \operatorname{IgG}(+)$ & 14 \\
\hline
\end{tabular}

Pada penelitian selama 2 tahun terdapat 21 anak yang mengalami dengue berat dirawat di PICU, sebanyak 5/21 penderita meninggal dunia. Perbandingan laki-laki dan perempuan 1:2,5. Hasil ini berbeda dengan penelitian yang dilakukan oleh Hung dkk. ${ }^{8}$ serta Tantracheewathorn dan Tantracheewathorn ${ }^{5}$ bahwa tidak terdapat perbedaan bermakna pada kedua jenis kelamin. Hasil yang didapatkan pada penelitian ini sesuai dengan penelitian oleh Cordeiro dkk. ${ }^{4}$ yang menemukan bahwa perempuan mempunyai risiko lebih tinggi untuk mengalami manifestasi klinis dengue yang lebih berat. Alasan mengapa perempuan memiliki risiko lebih tingi sampai saat ini masih belum jelas diketahui.

Sebagian besar penderita dengue berat pada penelitian ini berusia $1-5$ tahun tahun. Hal ini sesuai dengan penelitian terdahulu yang menyatakan bahwa anak di Asia Tenggara lebih sering menderita penyakit lebih berat karena kombinasi pejamu, faktor epidemiologi, dan virologi. ${ }^{3,4,8}$ Bayi dapat mengalami infeksi virus dengue berat pada saat infeksi pertama kali. ${ }^{2}$

Pada penelitian ini sebagian besar penderita $(16 / 21)$ berstatus gizi baik. Beberapa penelitian menyatakan bahwa tidak terdapat hubungan antara status gizi dan risiko terjadinya SSD. Penelitian terdahulu menyatakan bahwa malnutrisi dapat memengaruhi respons infeksi melalui penurunan imunitas selular, yang ditunjukkan oleh penurunan jumlah sel $\mathrm{CD}^{+} \mathrm{T}$-helper dan rasio $\mathrm{CD}^{+} / \mathrm{CD}^{+}$ yang rendah. Selain itu, terdapat penurunan produksi antibodi IgA sekretori, berbagai komplemen (C3, $\mathrm{C} 4$, dan faktor B) serta gangguan fagositosis. Hal tersebut mengakibatkan infeksi sekunder virus dengue tidak terlalu berat. ${ }^{5,8}$ Nilai hematokrit $\geq 35 \%$ ditemukan pada $9 / 21$ penderita. Penelitian terdahulu hemokonsentrasi merupakan faktor risiko terjadinya infeksi dengue yang berat. ${ }^{5,9}$ 
Faktor risiko paling besar terjadinya dengue berat, yaitu infeksi virus sekunder oleh serotipe virus yang berbeda dari sebelumnya. Beratnya penyakit pada infeksi sekunder berhubungan dengan titer virus dalam plasma yang lebih tinggi. ${ }^{2}$ Pemeriksaan serologis pada sebagian besar penderita menunjukkan infeksi sekunder ditandai dengan IgM dan IgG positif. Pada penelitian terdahulu menunjukkan bahwa di Asia infeksi sekunder terjadi pada periode yang lebih cepat karena ditemukannya sirkulasi salah satu dari keempat serotipe dengue, termasuk Indonesia. ${ }^{3,10}$ Penelitian sebelumnya juga telah membuktikan bahwa faktor risiko terjadinya dengue berat dalam hal ini SSD, yaitu infeksi sekunder atau virulensi virus yang tinggi. ${ }^{4,5}$

Lama perawatan di PICU pada penelitian ini sebagian besar selama $1-5$ hari $(9 / 21)$ dan $>5$ hari $(9 / 21)$. Penelitian oleh Shah dkk. ${ }^{11}$ menyatakan bahwa penderita SSD memerlukan waktu pemulihan serta terapi suportif lebih lama.

Manifestasi dengue berat akibat kebocoran plasma, perdarahan hebat, dan gangguan organ. ${ }^{2}$ Kebocoran plasma menyebabkan syok yang biasanya disertai akumulasi cairan dan menyebabkan gangguan respirasi. Syok hipovolemik pada dengue berat pada awalnya dapat terkompensasi, tekanan darah sistol normal, peningkatan tekanan darah diastol, tekanan nadi menyempit serta gejala hipoperfusi berupa kulit yang dingin dan mottled. Tanda-tanda syok sering kali terlambat dikenali karena penurunan tekanan darah biasanya terjadi pada fase lanjut dan penderita tetap sadar saat syok. Jika syok terus berlanjut dan tidak tertangani, maka akan terjadi kegagalan multiorgan. ${ }^{2}$

Manifestasi perdarahan yang sering ditemukan biasanya berupa perdarahan saluran cerna seperti hematemesis ataupun melena. Pada dengue berat, meskipun terjadi kelainan koagulasi dan trombositopenia yang bermakna, namun perdarahan yang mengancam jiwa jarang terjadi. Faktor risiko untuk terjadinya perdarahan signifikan yaitu syok berkepanjangan, terutama pada kasus yang diperberat dengan asidosis dan hipoksia. Faktor risiko lain terjadinya perdarahan, yaitu disfungsi hepar serta ginjal, penggunaan obat-obatan antiinflamasi nonsteroid, serta tindakan pemasangan pipa nasogastrik, pengambilan darah dari arteri, dan injeksi intramuskular. ${ }^{1,2}$

Gangguan organ yang berat merupakan kriteria diagnosis lain dengue berat meliputi gagal hati akut, ensefalopati/ensefalitis, gagal ginjal, serta disfungsi miokardium. Kematian akibat gangguan organ dapat terjadi sekalipun tidak terjadi kebocoran plasma. Kegagalan hati dapat terjadi sebagai akibat langsung virus yang menyebabkan hepatitis ataupun nekrosis fokal dan tingginya kematian. Peningkatan transaminase serum merupakan bagian dari dengue dan setelah resusitasi syok (hepatitis iskemik). ${ }^{2}$

Gangguan neurologis pada penderita dengue berat memiliki spektrum luas berupa ensefalopati, kejang, serta kelemahan akut otot-otot. Virus dengue berhasil diisolasi pada penderita yang mengalami ensefalitis. Pada fase lanjut, hipoperfusi serebral menyebabkan penurunan status mental, kejang, dan posisi ekstensi. Gejala neurologis tersebut membaik setelah syok teratasi. Penyebab lain terjadinya gejala neurologis, yaitu infeksi lain pada susunan saraf pusat (bakteri, virus, atau malaria), ensefalopati/ensefalitis, kelainan elektrolit, perdarahan intrakranial, serta gagal hati fulminan..$^{1,2}$

Manifestasi klinis dengue berat didapatkan sebagian besar berupa SSD pada $15 / 21$ penderita, KID pada $11 / 21$ penderita, dan ensefalopati $6 / 21$ penderita. Pada penelitian yang dilakukan oleh Chin dkk. ${ }^{12}$ ditemukan disfungsi organ multipel sebagai salah satu faktor risiko terjadinya gagal napas akut.

Selama 2 tahun penelitian terdapat 5 penderita dengue berat yang meninggal dunia, semuanya berusia $1-5$ tahun. Tiga dari lima penderita berjenis kelamin perempuan. Penyebab kematian pada 3 penderita karena SSD dengan KID, 1 penderita karena SSD dengan ARDS, serta 1 penderita karena SSD dengan ensefalopati.

Simpulan, dengue berat lebih banyak didapatkan pada anak perempuan, usia 1-5 tahun, serta status gizi baik. Manifestasi klinis dengue berat yang dominan berupa syok, koagulasi intravaskular diseminata, dan ensefalopati. Penyebab kematian tersering pada penderita dengue berat yaitu SSD dan KID.

\section{Daftar Pustaka}

1. WHO. Dengue haemorrhagic fever: diagnosis, treatment, prevention, and control. Geneva: WHO; 2009.

2. Ranjit S, Kissoon N. Dengue hemorrhagic fever and shock syndromes. Pediatr Crit Care Med. 2011;12(1):90-100.

3. Hammond SN, Balmaseda A, Perez L, Tellez Y, Saborio SI, Mercado JC, dkk. Differences in dengue severity in infants, children, and adults in a 3-year hospitalbased study in Nicaragua. Am J Trop Med Hyg. 2005;73(6):1063-70.

4. Cordeiro MT, Silva AM, Brito CA, Nascimento EJ, Magalhaes MC, Guimaraes GF, dkk. Characterization of a dengue patient cohort in Recife, Brazil. Am J Trop Med Hyg. 2007;77(6):1128-34. 
5. Tantracheewathorn T, Tantracheewathorn S. Risk factors of dengue shock syndrome in children. J Med Assoc Thai. 2007;90(2):272-7.

6. Karakus A, Banga N, Voorn GP, Meinders AJ. Dengue shock syndrome and rhabdomyolisis. Neth J Med. 2007;65(2):78-81.

7. WHO. WHO child growth standard 2007. [diunduh 1 September 2011]. Tersedia dari: http://www.who.int/childgrowth/en.

8. Nguyen TH, Nguyen TL, Lei HY, Lin HS, Le BL, Huang KJ, dkk. Association between sex, nutritional status, severity of dengue haemorrhagic fever, and immune status in infants with dengue hemorrhagic fever. Am J Trop Med Hyg. 2005;72(4):370-4.

9. Chacko B, Subramanian G. Clinical, laboratory and radiological parameters in children with dengue fever and predictive factors for dengue shock syndrome. J Trop Pediatr. 2008;54(2):137-40.
10. Porter KR, Beckett CG, Kosasih H, Tan RI, Alisjahbana B, Rudiman PI, dkk. Epidemiology of dengue and dengue hemorrhagic fever in a cohort of adults living in Bandung, West Java, Indonesia. Am J Trop Med Hyg. 2005;72(1):60-6.

11. Shah I, Despande GC, Tardeja PN. Outbreak of dengue in Mumbai and predictive markers for dengue shock syndrome. J Trop Pediatr. 2004;50(5):301-5.

12. Wang CC, Liu SF, Liao SC, Lee IK, Liu JW, Lin AS, dkk. Acute respiratory failure in adult patients with dengue virus infection. Am J Trop Med Hyg. 2007;77(1):151-8. 